\title{
Bacterial Degradation of Contaminated Soil using Organic Manure
}

\section{Fadina Olubunmi ${ }^{1}$, Solaja Olatunde ${ }^{2}$, Abiodun Abiodun ${ }^{2}$, Adetoyi Helen ${ }^{2}$}

\author{
${ }^{1}$ Department of Crop Protection and Environmental Biology, University of Ibadan, Ibadan, Nigeria. \\ ${ }^{2}$ Department of Environmental Health Technology, Ogun State College of Health Technology, Ilese-Ijebu, Nigeria. \\ Correspondence author-tolaja2004@yahoo.com.hk
}

\begin{abstract}
Soil contamination is the presence in soil of unwanted impure materials from human activities. Many techniques of remediation of contaminated soils have been developed such as physical, chemical, photo degradation etc. Biological treatments offer the best environmental friendly method for remediating hydrocarbons and other contaminated soils because it utilized the capability of the indigenious micro-organisms in the environment to break down the hydrocarbons and heavy metals into innocuous substances. This study investigated the abilities of bacterial isolated, identified from organic manure and determine the total petroleum hydrocarbon degradative potentials. $2 \mathrm{~kg}$ of soil was thoroughly mixed with $200 \mathrm{ml}$ and $400 \mathrm{ml}$ of spent oil to give $5 \%$ and $10 \%$ (w/w) each of organic manure , poultry litter(PL), cow dung $(C D)$ and mixed poultry litter and cow dung(MPLCD) was individually introduced into each spent oil contaminated soil and the rate of biodegradation was observed for a period of 12 weeks.The percentage of total petroleum hydrocarbon (TPH) loss was significantly higher in the soil contaminated with 5\% spent oil amended with MPLCD(40.46\%) followed by PL (35.53\%) and CD(27.70\%) while $32.42 \%$ loss only was recorded in the soil contaminated with $10 \%$ spent oil and amended with MPLCD while PL was $30.04 \%$ and $25.60 \%$ for CD. The hydrocarbon-utilizing bacteria isolated band identified includes Bacillus, Pseudomonas, Microccus and Staphyloccus. The amendment spent oil contaminated soil with organic manure enhances the rate of degradation of petroleum hydrocarbon. These additives can best be suited to remove or neutralize the contaminants in the soil.
\end{abstract}

Keywords - Bacteria, Total Petroleum Hydrocarbon, degradation, contaminated soil, organic manure.

\section{INTRODUCTION}

Soil contamination is the presence in soil of unwanted impure materials from human activities. It can also be the distortion of the soil environment by human activities. Soil is the habitat for variety of organisms, including fungi, bacteria, protozoa, insects, nematodes, worms, and many other animals. Viruses are also present in soils Contamination of soil environment by hydrocarbons (mostly petroleum hydrocarbons) is becoming prevalent across the globe. This is probably due to heavy dependence on petroleum as a major, source of energy throughout the world, rapid industrialization population growth and complete disregard for the environmental health. Leaks and accidental spills occur regularly during the exploration, production, refining, transport and storage of petroleum and petroleum products. Release of hydrocarbons into the environment whether accidentally or due to human activities is a main cause of water and soil pollution (Holliger et al., 1997). Also, (Fadina and Mbong 1998) reported that the contamination of soil with spent lubricating oil adversely affected micro and macro elements in soil, resulting in reduced growth and productivity patterns in two soybeans varieties.

Many techniques of remediation of contaminated soils have been developed, such as physical, chemical, degradation, photo degradation. However, most of these methods have some drawbacks in completely remediating hydrocarbon contaminated soil. Some of these methods leave behind daughter compounds which are more toxic to the environment than the parent compounds. Biological treatment offers the best environmental friendly method for remediating hydrocarbon and heavy metals contaminated soil because it utilized the capability of the indigenous microorganisms in the soil environment to break down the hydrocarbons and heavy metals into the innocuous substances. In Nigeria, most of the terrestrial ecosystem and shore lines in oil producing communities are important agricultural land under continuous cultivation. Any contact with crude oil usually results in damage to the soil, 
microorganisms and plants (Adedokun and Ataga, 2007). In urban areas of Nigeria, most mechanic workshops are poorly managed and can be sources of constant release of used spent oil discharged from the crank cases of vehicles, motorcycles, generators which can be aesthetically unsightly and cause serious environmental pollution. Biodegradation is favored as a good option for the remediation of polluted sites mainly because it uses inexpensive equipments, it is simple and environmentally friendly.

This method has been investigated by several research studies to remediate petroleum polluted soil using various nutrient sources such as inorganic fertilizer, Urea, sawdust, compost manure, and bio-solids ( Namhoong et al., 2002). Mushroom compost and Spent Mushroom Compost (SMC) have been applied in treating organic pollutants contaminated soils (Eggen, 1999, Trejo-Hernandez et al., 2006). Organisms such as fungi are also capable of degrading the hydrocarbons in engine oil to a certain extent but they take longer periods of time to grow when compared to their bacterial counterpart (Leeet al., 2007). Organic waste like banana skin, spent mushroom compost and brewery spent grain were found to enhance the biodegradation of used lubricating oil up to $90 \%$ within the period of 3 months (Abioye et al., 2009b, 2010).

Therefore, the main objective of this study is to isolate, identify the bacterial from degraded contaminated soil and determine the total petroleum hydrocarbon degradative potential of the intrinsic bacterial.

\section{METHODOLOGY}

\subsection{STUDY AREA:}

The experiment was carried out at the roof to garden of the Department of Crop Protection and Environmental Biology.

\subsection{COLLECTION AND PROCESSING OF SAMPLES.}

2.2.1 Soil sampling: The soil sample was collected randomly at a depth of $0-30 \mathrm{~cm}$ from the fallow field. They were bulked to form a composite sample and transported in polythene bags to the laboratory, air dried and sieved through a $2 \mathrm{~mm}$ mesh.

2.2.2 Spent Motor Oil: The spent motor oil used for the experiment was collected from a freshly drained motor car engine.

2.2.3 Collection of Poultry Litter and Cow Dung: The poultry litter (PL) and cow dung (CD) that was used was obtained from the Teaching and Research farm, University of Ibadan. The freshly collected manure was sun dried for 72 hours to allow moisture removal and accelerate the distribution of nutrients to the microbes.
2.2.4 Preparation of soil for Bioremediation - $2 \mathrm{Kg}$ of sieved $(2 \mathrm{~mm})$ soil was contaminated with $5 \%$ and $10 \%$ of spent lubricating oil and thoroughly mixed and left for 24 hours for homogenization. 10\% (w/w) of each organic manure, poultry litter (PL), cow dung (CD), mixed poultry litter and cow dung(MPLCD) was individually introduced into each spent oil contaminated soil and thoroughly mixed. The experimental pots were filled with the soil-oil - organic manure mixture. The control pots consist of soil-oil mixture without organic manure was also set up. The experiment was set up in four replicates. Periodic sampling from each experimental pot was carried out on day 0 and subsequently 4 weeks interval for 12 weeks of post contamination. Composite samples were obtained by mixing $5 \mathrm{~g}$ of soil collected from four different areas of the pots for isolation and enumeration of bacterial and also the determination of Total Petroleum Hydrocarbon (TPH).

Table.1: Experimental Design

\begin{tabular}{ll}
\hline \multicolumn{1}{c}{ Treatment } & Details of Treatment \\
\hline $1 \mathrm{~s}$ (control) & $2 \mathrm{~kg}$ soil $+5 \%$ spent oil. \\
2 (control) & $2 \mathrm{~kg}$ soil $+10 \%$ spent oil. \\
3 & $2 \mathrm{~kg}$ soil $+5 \%$ spent oil $+10 \% \mathrm{PL}$ \\
4 & $2 \mathrm{~kg}$ soil $+5 \%$ spent oil $+10 \% \mathrm{CD}$ \\
5 & $2 \mathrm{~kg}$ soil $+5 \%$ spent oil $+10 \%$ MPLCD \\
6 & $2 \mathrm{~kg}$ soil $+10 \%$ spent oil $+10 \% \mathrm{PL}$ \\
7 & $2 \mathrm{~kg}$ soil $+10 \%$ spent oil $+10 \% \mathrm{CD}$ \\
8 & $2 \mathrm{~kg}$ soil $+10 \%$ spent oil $+10 \% \mathrm{MPLCD}$ \\
\hline
\end{tabular}

Key:

$$
\begin{aligned}
& \mathrm{PL}=\text { Poultry litter } \\
& \mathrm{CD}=\text { Cow dung } \\
& \text { MPLCD = Mixed poultry litter and cow dung }
\end{aligned}
$$

\subsection{ENUMERATION AND IDENTIFICATION OF BACTERIAL POPULATION}

Four replicate samples from each oil- contaminated soil were withdrawn in every four weeks for the enumeration and identification of bacterial. $1 \mathrm{~g}$ of oil-contaminated samples were weighed and poured into $9 \mathrm{ml}$ of sterile distilled water and mixed thoroughly. Concentration of dilutions were made at $10^{1}$ to $10^{10}$ for bacterial. $0.1 \mathrm{ml}$ of dilution levels $10^{-2}, 10^{-4}$, $10^{-6}$, and $10^{-8}$ for bacterial was cultured using pour plate method on nutrient agar (NA), King B medium to determine the loads of Total Heterotrophic Bacteria (THB). All media, 
sterile distilled water were sterilized by autoclaving at $121^{\circ} \mathrm{C}$ for 15 milnutes.

The Nutrient Agar plates were incubated at $30^{\circ} \mathrm{C}$ for 48 hours, thus enumerating for only bacteria. The isolates from different plates were purified by repeated streaking on fresh agar medium.The characterization of isolates was based on the colonial, cell morphology and biochemical tests. The data obtained were compared with standards obtainable in Bergey's manual of the determinative bacteriology (Holt et al, 1994).

\subsection{PHYSICO - CHEMICAL PARAMETERS OF THE SOIL.}

The physical and chemical characteristics of the contaminated soil and the organic manure were determined.

2.4.1 Soil $\mathrm{pH}$ determination -- The $\mathrm{pH}$ was measured using Jenway $3510 \mathrm{pH}$ meter (Hendershot et al; 1993).

2.4.2 Determination of Organic Carbon (Walkley - Black Method)

2.4.3 Determination of Total Nitrogen (Kjeldahl Method) 2.4.4 Determination of Available Phosphorus (Bray11 method)

\subsubsection{Hydrometer method of Soil Mechanical Analysis}

\subsection{Total Petroleum Hydrocarbon (TPH) Analysis}

This was carried out using the method of Adesodun and Mbagwa (2008). Ten grammes (10g) of soil samples were weighed into $50 \mathrm{ml}$ flask and $20 \mathrm{ml}$ Toluene (Analar Grade) was added. After shaking for 30 minutes on an orbital shaker ,the liquid phase of the extract was measured at $420 \mathrm{~nm}$ (nanometer) absorbance using DR/4000 Spectrophotometer. The Total Petroleum Hydrocarbon in the soil was estimated with the reference to a standard curve derived from fresh used engine oil diluted with Toluene.

\subsection{Procedure for Preparing Standard Curve for TPH Analysis}

Preparation of the standard solution was by diluting $0.2 \mathrm{ml}$ of fresh spent oil in $100 \mathrm{mls}$ of Toluene to give 2000ppm. It was then filled into the $100 \mathrm{ml}$ flask to meet the required mark using Toluene.
Preparation of 100ppm, 200ppm, 300ppm, 400ppm, 500ppm and 600ppm from the stock solution using the formula $\mathrm{C}_{1} \mathrm{~V}_{1}$ $=\mathrm{C}_{2} \mathrm{~V}_{2}$,

$$
\begin{aligned}
& \text { Where, } \mathrm{C}_{1}=\text { Concentration of stock solution } \\
& \qquad \begin{array}{l}
\mathrm{V}_{1}=\text { Unknown volume } \\
\mathrm{C}_{2}=\text { Concentration of desired }
\end{array}
\end{aligned}
$$

solution e.g. $100 \mathrm{ppm}$

$$
\mathrm{V}_{2}=\text { Desired volume e.g. } 10 \mathrm{ml}
$$

The concentration of each volume was put in a $10 \mathrm{ml}$ flask and add more Toluene till it reaches the desired mark. The absorbance for each concentration was taken using the spectrophotometer and plotting the calibration curve of Absorbance value against concentration

\section{RESULTS}

Physico-chemical Parameters: The physicochemical properties of the contaminated soil and the organic manure are shown below in Table 2. The soil had a $\mathrm{pH}$ of $6.31 \pm 0.55$ and a low concentration of total nitrogen, organic carbon, organic matter and available phosphorus as $3.65 \pm 0.51 \%$, $10.35 \pm 0.28 \% ; \quad 17.89 \pm 0.38 \%$ and $18.34 \pm 0.36 \mathrm{mg} / \mathrm{kg}$ respectively. The organic manure used comprised of Poultry litter, cow dung and the mixed Poultry litter and cow dung which had a $\mathrm{pH}$ of $8.60 \pm 0.25 ; 8.20 \pm 0.28$ and $9.60 \pm 0.36$ respectively. The mixed Poultry litter and cow dung had a higher percentage of total nitrogen of $6.50 \pm 0.64 \%$ followed by Poultry litter of $6.00 \pm 0.95 \%$ and cow dung $5.20 \pm 0.64 \%$. Whereas, the available phosphorus of Poultry litter is $25.00 \pm 0.24 \mathrm{mg} / \mathrm{kg}$; cow dung is $22.00 \pm 0.25 \mathrm{mg} / \mathrm{kg}$ while the phosphorus of mixed poultry litter and cow dung was $24.00 \pm 0.12 \mathrm{mg} / \mathrm{kg}$. The poultry litter, cow dung and the mixed poultry litter and cow dung had an organic carbon (\%) of $17.17 \pm 0.16 ; 16.92 \pm 0.67$ ad $17.20 \pm 0.35$ respectively while the total organic matter (\%) was higher $29.74 \pm 0.16 \%$ in the mixed poultry litter and cow dung when compared with the low percentage recorded in poultry litter $29.69 \pm 0.28 \%$ and cow dung litter $29.69 \pm 0.28 \%$ and cow dung $29.25 \pm 0.46 \%$. The moisture content was higher in contaminated soil $(39.00 \pm 0.20 \%)$ compared to the organic manure of poultry litter of $17.20 \pm 0.06 \%$; cow dung $16.81 \pm 0.68 \%$ and mixed poultry litter and cow dung of $11.35 \pm 0.24 \%$.

\section{2: Physicochemical Parameters of Contaminated soil and Organic manure.}

\begin{tabular}{lllll}
\hline Properties & Contaminated soil & PL & CD & MPLCD \\
\hline pH & $6.31 \pm 0.55$ & $8.60 \pm 0.25$ & $8.20 \pm 0.28$ & $9.60 \pm 0.36$ \\
Total Nitrogen (\%) & $3.65 \pm 0.51$ & $6.00 \pm 0.95$ & $5.20 \pm 0.64$ & $6.50 \pm 0.64$ \\
Available phosphorus (\%) & $18.34 \pm 0.36$ & $25.00 \pm 0.24$ & $22.00 \pm 0.25$ & $24.00 \pm 0.12$
\end{tabular}




\begin{tabular}{lllll} 
Total Organic carbon (\%) & $10.35 \pm 0.28$ & $17.17 \pm 0.16$ & $16.92 \pm 0.67$ & $17.20 \pm 0.35$ \\
Total organic matter (\%) & $17.89 \pm 0.38$ & $29.69 \pm 0.28$ & $29.25 \pm 0.46$ & $29.74 \pm 0.16$ \\
Moisture content (\%) & $39.00 \pm 0.20$ & $17.20 \pm 0.06$ & $16.81 \pm 0.68$ & $11.35 \pm 0.24$ \\
Sand (\%) & $87.50 \pm 0.70$ & & & \\
Silt (\%) & $5.15 \pm 0.64$ & & & \\
Clay (\%) & $7.35 \pm 0.07$ & & & \\
\hline
\end{tabular}

Means of triplicate \pm standard deviation

PL: Poultry litter

CD: Cow Dung

MPLCD: Mixed Poultry litter and cow dung.

Baseline total Heterotrophic microbial population counts in the contaminated soil and organic manure.

The result in table 3 shows the total heterotrophic bacteria in the contaminated soil and the organic manure. The total heterotrophic bacteria counts in the contaminated soil of $5 \%$ and $10 \%$ was $0.76 \pm 0.28 \times 10^{3} \mathrm{cfu} / \mathrm{g}$ and $0.32 \pm 0.35 \times 10^{3} \mathrm{cfu} / \mathrm{g}$ Whereas the total heterotrophic counts of bacteria in poultry litter, cow dung and the mixed poultry litter and cow dung was $1.32 \pm 0.15 \times 10^{6} \mathrm{cfu} / \mathrm{g} ; 2.00 \pm 0.11 \times 10^{6} \mathrm{cfu} / \mathrm{g}$ and $2.68 \pm 0.15 \times 10^{6} \mathrm{cfu} / \mathrm{g}$ respectively.

3: Baseline Total Heterotrophic microbial population counts in the contaminated soil and organic manure.

\begin{tabular}{ll}
\hline Samples & Total heterotrophic bacteria \\
\hline (Control)Contaminated soil with 5\% spent oil & $0.76 \pm 0.28 \times 10^{3}$ \\
(Control)Contaminated soil with 10\% spent & $0.32 \pm 0.35 \times 10^{3}$ \\
oil & \\
Poultry Litter (PL) & $1.32 \pm 0.15 \times 10^{6}$ \\
Cow dung (CD) & $2.00 \pm 0.11 \times 10^{6}$ \\
Mixed Poultry Litter and Cow Dung & $2.68 \pm 0.15 \times 10^{6}$ \\
\hline
\end{tabular}

4: Cultural and Biochemical characteristic of pure bacteria species isolated from degrading contaminated soil.

\begin{tabular}{lllll}
\hline Test & Bacillus $\mathbf{s p}$. & Staph $\mathbf{s p}$. & Micrococcus $\boldsymbol{s p}$. & Pseudomonas sp. \\
\hline Colony shape & Circular & Irregular & Circular & Circular \\
Elevation & Raised & Flat & Raised & Flat \\
Cell shape & Rod & Cocci & Cocci & Rod \\
Pigmentation on Nutrient agar & Yellow & Yellow & Cream & Greenish \\
Gram stain & + & + & + & - \\
Catalase & - & + & - & + \\
Motility & + & - & - & + \\
Oxidase & + & - & - & - \\
Spore stain & + & - & - & - \\
King-B-medium & None & None & None & Greenish \\
Temperature: $\mathbf{2 8 . 5 \pm \mathbf { 2 } ^ { \mathbf { 0 } } \mathbf { C } .}$ & + & + & + & + \\
\hline
\end{tabular}

$\begin{array}{lll}+ & = & \text { Positive reaction } \\ - & = & \text { Negative reaction }\end{array}$




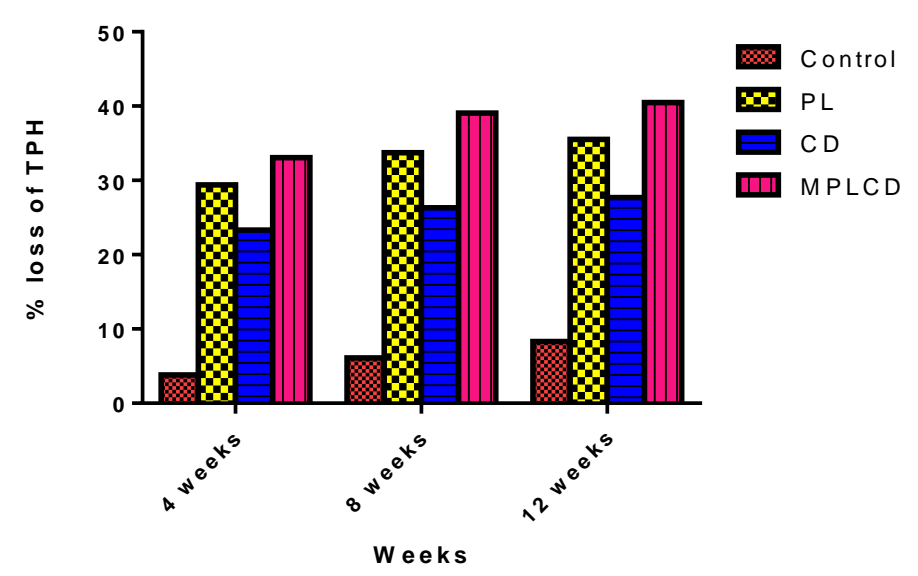

Fig 1. - Percentage loss of Total Petroleum Hydrocarbon in a contam inated soil with $5 \%$ spent oil.

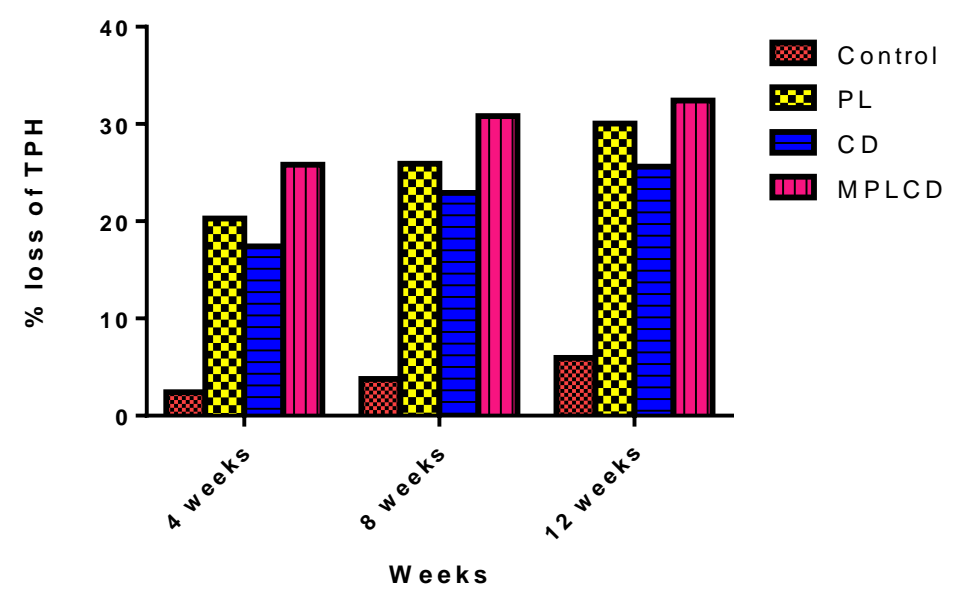

Fig 2. - Percentage loss of Total Petroleum Hydrocarbon in a contaminated Soil with $10 \%$ Spent Oil.

Figure 1 and 2 shows marked percentage loss of Total Petroleum Hydrocarbon content during the period of study with the addition of different organic manures (Poultry litter, cow dung and mixed poultry litter and cow dung). At the end of the first 4 weeks of the study, the contaminated soil with $5 \%$ spent oil $(50000 \mathrm{mg} / \mathrm{kg}-1)$ showed a significant in total petroleum hydrocarbon loss of $29.38 \% ; 23.32 \%$ and $33.07 \%$ in the soil amended with PL, CD and MPLCD respectively compared with the unamended control contaminated soil of $3.83 \%$ while there was low degradation of hydrocarbon in the soil contaminated with $5 \%$. The contaminated soil with $10 \%$ spent oil $(100000 \mathrm{mg} / \mathrm{kg}-1)$ showed a significant loss in total petroleum hydrocarbon content of $20.27 \% ; 17.41 \%$ and
$25.83 \%$ in to contaminated soil amended with poultry litter, cow dung and mixed poultry litter and cow dung whereas $2.4 \%$ reduction from the control contaminated soil.

AT 8 weeks of the study, there was a reduction in the degradation of contaminated soil with $5 \%$ spent oil amended with poultry litter was $33.73 \%$, cow dung was $26.32 \%$ while mixed poultry litter and cow dung loss $39.07 \%$ and the unamended control soil loss $6.10 \%$. Also, the contaminated soil with $10 \%$ spent oil, loss of total petroleum hydrocarbon content in the soil amended with poultry litter was $25.93 \%$, cow dung $22.93 \%$ and for mixed poultry litter and cow dung was $30.83 \%$ while the unamended control soil loss $3.80 \%$. 
AT the end of 12 weeks, there was a significant loss of total petroleum hydrocarbon content in the amended contaminated soil with $5 \%$ and $10 \%$.

The level of total petroleum hydrocarbon loss in the amended contaminated soil with $5 \%$ spent oil was for poultry litter $35.53 \%$,cow dung $27.70 \%$ and mixed poultry litter and cow dung was $40.46 \%$ while unamended control soil was $8.32 \%$. However, for contaminated soil with $10 \%$ of spent oil, a significant reduction of $30.04 \%, 25.60 \%$ and $32.42 \%$ respectively for poultry litter,cow dung and mixed poultry litter and cow dung whereas the total petroleum hydrocarbon content loss in the unamended control soil was $5.95 \%$.

AT the end of the study, it was observed that the organic manure applied showed a tremendous degradation in the contaminated soil with spent oil. The high degradation of contaminated soil occurred in the soil amended with mixed poultry litter and cow dung. This can be due to the presence of consortium of microbes which enhances the biodegradation of spent oil from the soil.

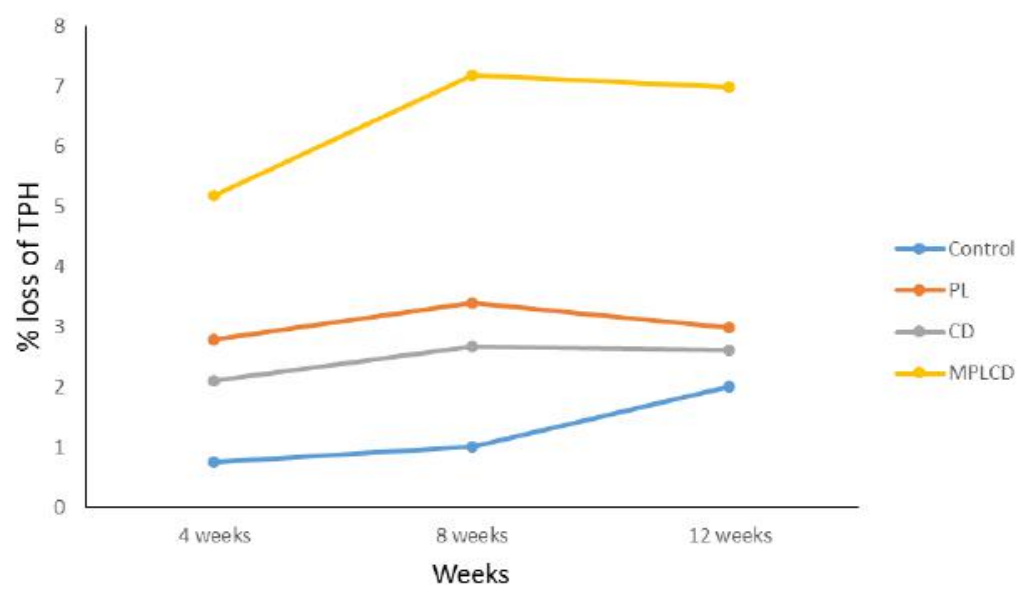

Fig 3:- Counts of Hydrocarbon - utilizing bacteria population in soil contaminated with $5 \%$ spent oil (cfu/g).

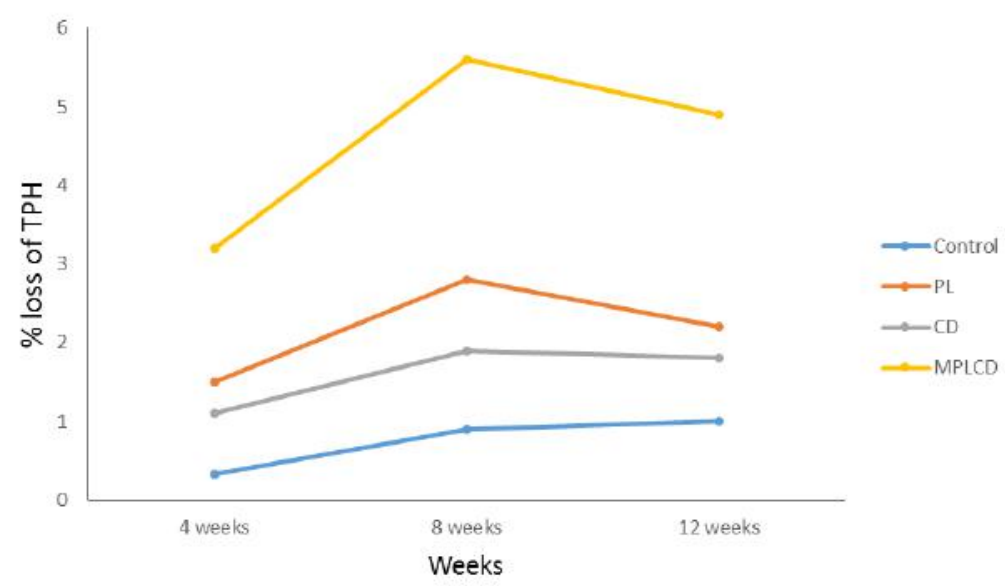

Fig 4:- Counts of Hydrocarbon - utilizing bacteria population in soil contaminated with 10\% spent oil (cfu/g).

Figure 3 and 4 presented the heterotrophic counts of hydrocarbon - utilizing bacteria population in the soil contaminated with $5 \%$ and $10 \%$ spent oil. The hydrocarbon utilizing bacteria population counted in the amended soils with $5 \%$ spent oil contaminated at the end of first 4 weeks. $2.80 \pm 0.16 \times 10^{6}$ for poultry litter; $2.10 \pm 0.95 \times 10^{6}$ for cow dung and the mixed poultry litter and cow dung was 
$5.20 \pm 1.55 \times 10^{6}$ while the unamended control soil was $0.76 \pm 0.16 \times 10^{6} \mathrm{cfu} / \mathrm{g}$.

Also the contaminated soil with $10 \%$ spent oil showed hydrocarbon - utilizing bacteria population in the amended soil contaminated as poultry litter was $1.50 \pm 0.16 \times 10^{6}$, cow dung was $1.10 \pm 0.74 \times 10^{6}$ and mixed poultry litter and cow dung was $3.20 \pm 1.11 \times 10^{6}$ while in an unamended control was $0.32 \pm 0.06 \times 10^{6}$

AT 8 weeks of treatment application, the level of hydrocarbon - utilizing bacteria counts from the contaminated soil with 5\% spent oil for poultry litter was $3.40 \pm 0.67 \times 10^{6}$, cow dung was $2.68 \pm 0.45 \times 10^{6}$ and the mixed poultry litter and cow dung was $7.20 \pm 1.11 \times 10^{6}$ while that of the unamended soil was $1.01 \pm 0.12 \times 10^{6} \mathrm{cfu} / \mathrm{g}$. The hydrocarbon - utilizing bacteria counted for the soil contaminated with $10 \%$ spent oil was $2.80 \pm 0.15 \times 10^{6}$ for poultry litter, $1.90 \pm 0.10 \times 10^{6}$ for cow dung and $5.60 \pm 0.64 \times$ $10^{6}$ for mixed poultry litter and cow dung while the value for unamended control soil was $0.90 \pm 0.06 \times 10^{6} \mathrm{cfu} / \mathrm{g}$.

At the end of 12 weeks, of the study, the counts of hydrocarbon - utilizing bacteria in the soil contaminated with $5 \%$ spent oil was $2.00 \pm 1.19 \times 10^{6}$ for the unamended control soil, the amended contaminated soil with poultry litter, cow dung and the mixed poultry litter and cow dung was $3.00 \pm 0.15 \times 10^{6}, 2.62 \pm 0.60 \times 10^{6}$ and $7.00 \pm 0.10 \times 10^{6} \mathrm{cfu} / \mathrm{g}$ respectively. While with $10 \%$ spent oil contaminated soil, the amended contamination soil was $2.20 \pm 1.60 \times 10^{6}$ for poultry litter, $1.80 \pm 0.10 \times 10^{6}$ for cow dung and the mixed poultry litter and cow dung was $4.90 \pm 1.22 \times 10^{6}$ while the uamended control soil was $1.00 \pm 0.25 \times 10^{5}$.

It was observed that the organic manure added had a greater microbial population in the amended contaminated soil. However towards the end of the study, there was a microbial population drop in the treatment which is also similar to the $10 \%$ spent oil contaminated soil. Microbial counts was significantly higher in soil amended with different organic manures when compared to those of the unamended control.

Contaminated soil at the $0.05 \%$ probability level, indicating the role of nutrients in the enhancement of microbial population. There was a significantly higher hydrocarbon utilizing microbial population in the mixed poultry litter and cow dung than those amended with cow dung and poultry litter while the microbial population in the poultry litter was significantly higher $(\mathrm{P}<0.05)$ than the cow dung. The hydrocarbon - utilizing microbial population in the contaminated soil with $10 \%$ spent oil exhibited a similar trend as observed in 5\% concentration of hydrocarbon utilizing bacteria at $0.05 \%$ probability level in the soil amended with organic manures. The result of the microbial population obtained demonstrated microbial population in the different organic manures:

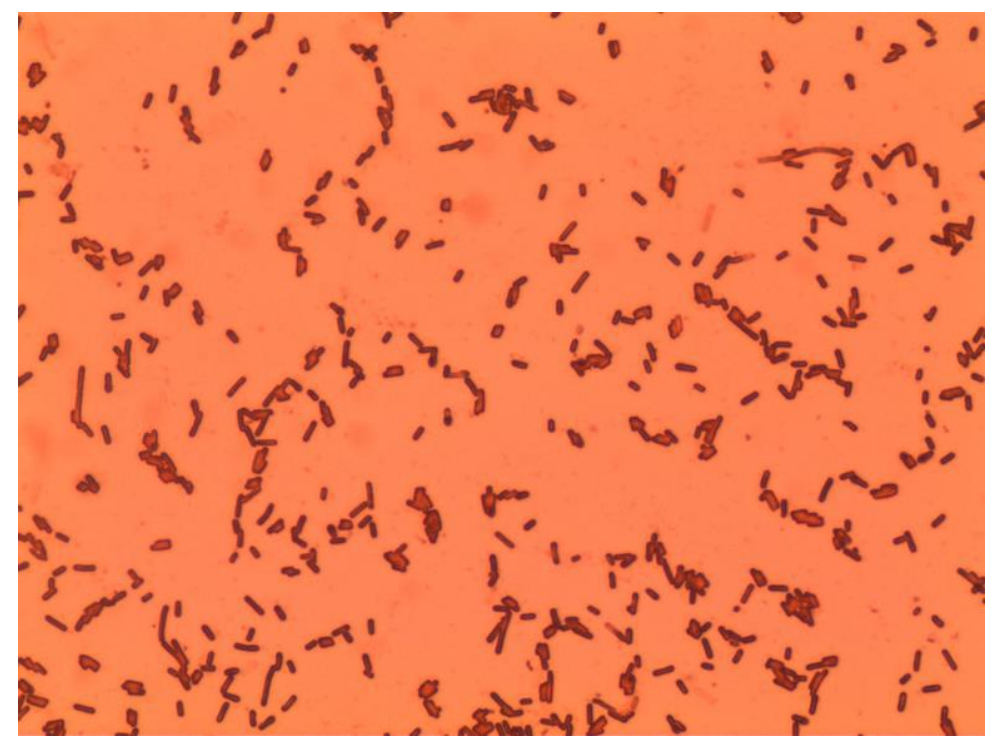

Plate 1: Isolated Rod of Pseudomonas specie 


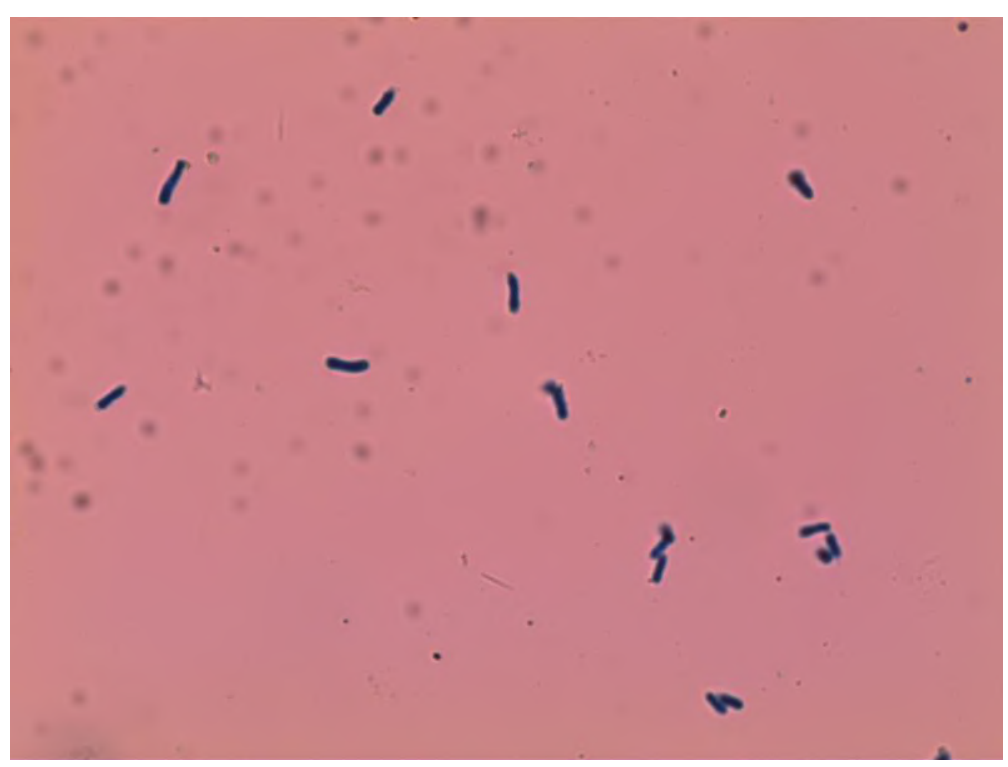

Plate 2: Isolated Rod of Bacillus specie

\section{DISCUSSION}

The findings in this research indicated that the $\mathrm{pH}$ value obtained for poultry litter, cow dung and the mixed poultry litter and cow dung was $8.60 \pm 0.25,8.20 \pm 0.28$ and $9.60 \pm$ 0.35 respectively. This was an indicative of the alkaline nature of the organic manure samples used. This condition of alkalinity may be responsible for the high counts of total heterotrophic and hydrocarbon-utilizing bacteria. This difference was supported by the reports of Ijah and Abioye, (2003); Njoku et al. (2009) that bacteria thrive better in alkaline medium than acidic medium.

The particles size analysis of the soil samples indicated that the soil was sandy. This is because the sand percentage of the soil samples was $87.50 \%$.

The nitrate content was higher in the organic manure used compared to the contaminated soil. This may be due to the presence of high nitrogenous compounds in the poultry litter, cow dung and the mixed poultry litter and cow dung.sA similar result was reported by Atagana (2008) who worked on compost manure. This result also agrees with the findings of Okwule and Ijah (2014) who observed higher nitrate contents in palm oil mill effluent soil (POME) amended with poultry droppings added to the contaminated soil enhances the growth of bacterial and fungal in the biodegradation process.

The presence of moisture content may also support the growth and survival of these microbes and providing moisture necessary for their bioactivity. This may arise from the rain since this study was carried out during the early rainy season (March-May, 2016). This is in agreement with Stephen and Egene, (2012) who observed high moisture content in the spent lubricating oil polluted soil during the rainy season.

The organic carbon and organic matter contents were higher in the organic manure used, carbon and organic matters were utilized by the microorganisms for their growth and metabolic activities. Carbon also serves as a source of nutrients and also required for biodegradation. Lee et al., (2003), reported that the addition of carbon in the form of pyruvate stimulates the microbial growth and enhances the rate of polycyclic aromatic hydrocarbons (PAHs)

Phosphorus content of the poultry litter, cow dung, and mixed poultry litter and cow dung was higher compared to that of the contaminated soil. The presence of these organic manures contributed to the higher content of phosphorus which was used by micro-organisms during the biodegradation process and this was reported by Ijah and Abioye (2003).Also, Thieman and Palladino (2009) reported that high level of Nitrogen and Phosphorus in the organic manure added to the contaminated soil enhances the growth of bacterial and fungal in the biodegradation process. Microorganisms play an important role in the degradation of environmental pollutants. Microbial growth and metabolism in the impacted areas can be mitigated by a number of factors such as $\mathrm{pH}$, temperature, concentration of pollutant, moisture content, conductivity, oxygen content, nutrient availability and bioavailability and the property of the impacted soil medium (Rahman et al.,2001). 
The organic manure used (poultry litter, cow dung and the mixed poultry litter and cow dung) contained considerable numbers of heterotrophic and hydrocarbon degrading bacteria. The counts of total heterotrophic microbes were higher compared to the hydrocarbon degrading microbial population. The reason for higher counts of total heterotrophic bacteria may be attributed to the fact that hydrocarbon degrading bacteria are also heterotrophic. Naturally, they are part of the heterotrophic community. The high counts of petroleum hydrocarbon degrading microbes in the sample is therefore suggestive of previous exposure to oil contamination this will ultimately boost the supply of carbon and hence, favours the growth of these microbes (Ijah and Abioye, 2003).

The microbial population of hydrocarbon degrading microorganisms in an ecosystem quantitatively reflects the degree or extent of exposure of that ecosystem to hydrocarbon contamination.Ijah and Antai (2007) reported that the high counts of the total heterotrophic bacteria and fungi in organic manure may be the result of the presence of appreciable quantities of Nitrogen and phosphorus which can enhances the multiplication of bacteria and fungi in the soil.

The result of the investigation has shown that four bacterial genera were tested for petroleum hydrocarbon degradative potentials. This was revealed that these microbes exhibited responses and potential to breakdown petroleum hydrocarbon and utilize as source of energy and carbon. All the bacteria exhibited the highest degradative potentiality during the period of study. Onuoha et al., 2014 suggested that the differences in the rate of hydrocarbon degradation may be due to the natural ability of the microbes in the hydrocarbon degradation. The petroleum hydrocarbon- utilizing bacteria isolated and identified were to be the species of Pseudomonas, Bacillus, Micrococcus and Staphylococcus. These bacteria species has been implicated in the hydrocarbon degradation by the authors (Onuoha et al., 2011; Ijah, 1998) Okpokwasili and Okorie (1990) isolated similar hydrocarbon- utilizing bacteria from the Niger- Delta aquatic systems. Chikere and Okpokwasili (2004) also made similar findings on petroleum effluents. It has also been observed that some microorganisms are more abundant in areas of high concentration of hydrocarbons. These micro floras are actively oxidizing the hydrocarbons and this is considered as another source of carbon for use in the ecosystem. This study revealed that, the indigenous microbial populations in the oil contaminated soils are capable of mineralizing these pollutants in the environment to the safe and acceptable level. There was a general increase in the hydrocarbon utilizing microbial population in the treatment for both $5 \%$ and $10 \%$ spent oil contaminated soil. Whereas the un-amended control soil exhibited lowest rate in the microbial population. This relatively lowest rate obtained may have resulted from the toxicity of spent oil to the soil micro-organisms, brought about by the high concentration of the spent oil before the remediation treatments. This was also observed by Odokuma and Dickson, 2003.

The first 8 weeks exhibited significant increase in the hydrocarbon- utilizing microbial population, and towards the end of the research, there was a decrease in the microbial population which may be due to the decline in the availability of readily metabolizable components of hydrocarbon for the organisms.

The counts of microbial population of hydrocarbon- utilizing bacteria in the $5 \%$ and $10 \%$ spent oil contaminated soil amended with different organic manure in the study were significantly higher $(\mathrm{p}<0.05)$ when compared with those of the unamended control soil. These counts are similar to those of Ijah and Antai (2003b), who observed counts of hydrocarbon degraders in oil polluted soil to be $x 10^{6} \mathrm{cfu} / \mathrm{g}$.

The reasons for the significant higher counts of bacteria in the amended contaminated soil may be due to the availability of appreciable quantities of nitrogen and phosphorus from the organic manure added to the contaminated soil which enhances the multiplication of bacteria. (Thieman and Palladino, 2009; Adesodun and Mbagwu, 2008). Also, it was observed that the decrease in the hydrocarbon- utilizing bacteria towards the end of the study was as a result of the decline in the availability of readily nutrients for the growth of the microbes which have been reported also by Vasudevan and Rajaram, 2001.

This study also revealed that the biodegradation of oil breakdown increases with time. The different organic manure added to the contaminated soil significantly enhanced the degradation of the contaminated soil in comparison with the control soil without the addition of organic manures. This might be as a result of released nutrients from the organic manure into the contaminated soil for use by the oil degraders. This finding is in consistent with the work done by Abioye et al., 2009b who used banana skin (BS), brewery spent grains (BSG) and spent mushroom compost (SMC) as organic waste amendments in the biodegradation of used motor oil in soil.

It was observed that the high concentration of oil contamination has a reduced effect on the rate of microbial reduction of total petroleum hydrocarbon. The ineffectiveness of the organic manure with high 
concentration of oil could be attributed to the reduction in the activity of the soil microbes at that level of oil pollution. Ijah and Antai (2003) reported high degradation of hydrocarbon in soil contaminated with $10 \%$ and $20 \%$ crude oil compared to those contaminated with $30 \%$ and $40 \%$ crude oil which experienced partial degradation within a period of 12 months. Also, it is important that the reduction or loss in total petroleum hydrocarbon in the contaminated soil may not only be due to the biodegradation process included by nutrient additions, but other processes such as volatilization, adsorption to organic compounds and other abiotic factors are equally implicated in the reduction process. This is the case in the two un-amended control soils where there were reductions in total petroleum hydrocarbon without any organic manure amendment.

\section{CONCLUSION}

The amendment of spent oil contaminated soil with organic manure enhances significantly the rate of biodegradation of petroleum hydrocarbon. The spent oil contaminated soil amended with mixed poultry litter and cow dung with 5\% and $10 \%$ spent oil contamination exhibited highest rate of oil biodegradation and counts of hydrocarbon- utilizing bacteria compared to the soil amended with poultry litter and cow dung.

The un-amended control soil also showed that the remediation of the contaminated soil can be achieved through natural processes of biodegradation, photo-oxidation, evaporation and volatilization without external interferences.

\section{REFERENCES}

[1] Abioye PO, Abdul-Aziz A, Agamuthu P (2010). Enhanced biodegradation of used engine oil in soil amended with organic wastes. Water, Air, Soil Pollution, 209:173-179.

[2] Abioye, O.P, Alonge, O.A, Ijah, U.J.J. (2009a) Biodegradation of crude oil in soil amended with melon shell. Assumption University Journal of Technology 13(1): 34 - 38.

[3] Abioye, O.P., Abdul Aziz, A and Agamuthu, P.(2009b). Stimulated biodegradation of used lubricating oil in soil using organic wastes. Malaysian Journal of Science. 28 (2):127133.

[4] Adams G.O,Tawari-Fufeyin and Igelenyah Ehinomen (2014). Bioremediation of spent oil contaminated soils using poultry litters. Research Journal in Engineeringand Applied Sciences 3(2) 118-124.

[5] Adedokun,O.M and Ataga, A.E.(2007).Effects of amendments and bioaugumentation of soil polluted with crude oil, automotive gasoline oil and spent engine oil on the growth of cowpea (Vigna unginiculata L.Walp). Scientific Research and Essay Vol.2(5);137-149.
[6] Adesodun, J.K. and Mbagwu, J.S.C (2008). Biodegradation of waste lubricating petroleum oil in a tropicalalfisol as mediated by animal droppings. Bioresource Technology, 99: 5659 5665.

[7] American Health Public Health Public Association (APHA) (1998). Standard Method for the examination of water and waste water, Washigton, DC

[8] Antai, S.P and Mgbomo (1989). Distribution of hydrocarbon utilizing bacteria in oil-spill areas. Microbiology Letters, 40:137-143

[9] AOAC (2003) Methods of analysis of Association of Offical Analytical Chemists (16th ed) Washinton, D.C 1:600-792

[10] Atagana HI. Compost bioremediation of hydrocarbon contaminated soil inoculated with organic manure. African Journal of Biotechnology. 2008;7(10):1516-1525.

[11] Atlas RM (1984). Pathways of the hydrocarbon degradation In Petroleum Microbiology Macmillan publishing company, New York. pp 1-15. .

[12] Bartha,R.(1986). Biotechnology of pollutant biodegradation. MicrobialEcology.12; 155-172

[13] Beeby, A., (1993). Measuring the effect of pollution. Int. Applying Ecology. Chapman and Hall, London, New York.

[14] Bento, F.M., Camargo, F.O.A., Okeke, B.C., Frankenberger, W.T., (2005). Comparative bioremediation of soils contaminated with diesel oil by natural attenuation, biostimulation and bioaugmentation. Bioresource Technology 96: 1049-1055.

[15] Bumpus J. A (1989) Biodegradation of polycyclic aromatic hydrocarbons by phanerochaete chrysosporium. Applied Environmental Microbiology 55; 154-158

[16] Dowling DN, D. SL, Improving phytoremediation through biotechnology, Curr Opin Biotechnol 20 (2009) 204-209

[17] Eggen, T. (1999). Application of fungal substrate from commercial mushroom production Pleurotus ostreatus for bioremediation of creosote contaminated soil. International Biodeterioration and Biodegradation, 44:117-126.

[18] Holt JG, Kreig NR, Sneath PHA, Stanley J.T, William ST (1994). Bergey's manual of Determinative Bacteriology. Baltimore, USA: William and Wikins 213pp.

[19] Husaini, A. Roslan.H.A.,Hii K.S.Y. and Ang C.H.,(2008) Biotechnology of aliphatic hydrocarbon by indigenous fungi isolated from used motor oil contaminated sites. World Journal of Microbiology andBiotechnology,vol.24,no.12,pp 2789-2797.

[20] Ijah U.J.J, Abioye O.P (2003) Assessment of physicochemical and microbiological properties of soil 30 months after kerosene spill. J. Res.Sci. Manag., 1(1): 24-30.

[21] Ijah, U.J.J (1998). Studies on relative capabilities of bacterial and Yeasts isolates from tropical soils in degradingcrude oil. Waste Management, 18: 293-299.

[22] Ijah, U.J.J and Antai, S.P (2003a). The potential use of chicken-drop microorganisms for oil spill remediation.The Environmentalist, 23:89-95 
[23] Ijah, U.J.J and Antai, S.P. (2003b) Removal of Nigerian light crude oil in soil over a $12-$ month period. International Biodeterioration and Biodegradation, 51: 93-99.

[24] Ijah, U.J.J and Ndana, M (2000). Stimulated biodegradation of crude oil in soil amended with periwinkle shells. The Environmentalist, 23: 249-254.

[25] Knopp D, Vaananen V, Niessner R Determination of polycyclic aromatic hydrocarbons in contaminated water and soil samples by immunological and chromatographic methods., Environ Sci Technol 34 (2000) 2035-2041

[26] Kotas J and Stasicka Z. (2000) - Chromium occurrence in the environment and methods of its speciation. Environmental pollution 107: 263-283

[27] Krebs, C. T., Tanner, C. E., (1981). Restoration of oiled marshes through sediment stripping and Spartina propagation. Proceeding of the 1981 oil spill conference, American petroleum institute, Washington DC .,375-385.

[28] Namkoong, W., Hwang, E., Park, J and Choi, J. (2002). Bioremediation of diesel- contaminated soil with composting. Environmental Pollution, 119: 23-31

[29] Njoku KL, Akinola MO, Oboh BO (2009). Phytoremediation of crude oil contaminated Soil: The Effect of growth of glycine max on the physico-chemistry and crude oil contents of soil. Nature and Science, http//www.sciencepub. net/nature :22-30.

[30] Obire,O. and Amusan, F.O (2003). The Environmental Impacts of Oilfield Formation Water on a freshwater Stream in Nigeria .Journal of Applied Scienceand Environmental Management. 7; 61-66.

[31] Odeyemi O (2014). Two centuries of oil and gas (1860-2060) www.universalacademicservices.org

[32] Odokuma LO, Dickson AA (2003). Bioremediation of crude oil polluted tropical mangrove environment. J. Appl. Sci. Environ. Manage., 7(2): 23-29.

[33] Odokuma, L. O. and Ibor, M. N. (2002) Nitrogen fixing bacteria enhanced bioremediation of crude oil polluted soil. Global Journal of Pure and AppliedSciences. 8 (4): 455-468.

[34] Odokuma, L.O and Dickson, A.A. (2003) Bioremediation of a crude oil - polluted tropical rain forest soil. Global Journal of Environmental Sciences, 2: 29-40

[35] Odokuma, L.O and Okpokwasili, G. C(1993). Seasonal ecology of hydrocarbon-utilizing microbes in the surface water of a river. Environment Assess 27(3) 175-191.

[36] Okpokwasili, G.C. and Amanchukwu, S.C. (1988).Petroleum Hydrocarbon degradation by Candida Species. Environ. Int. 14: 243-247.

[37] Okpokwasili, G.C. and Okorie, B.B. (1988). Biodeterioration potentials of microorganisms isolated from car engine lubricating oil. Tribol. Int. 21: 215-220.

[38] Onuoha, S.C., Olugbue, V.U., Uraku, J.A and Uchendu, D.O (2011). Biodegradation potentials of hydrocarbon degraders from waste -lubricating oil spilled soils in Ebonyi State,
Nigeria. International Journal of Agriculture andBiology, 13:586-590.

[39] Thieman, W.J., Palladino, M.A. (2009). Introduction to biotechnology, 2nd edition. Pearson, New York, pp $209-$ 222.

[40] Trejo - Hernandez MR, Ortiz A, Okoh AI, Morales D, Quintero R (2007). Biodegradation of heavy crude oil Maya using spent compost and sugar cane bagasse waste. Chemosphere 68: 848-855. 